\title{
HUMAN RESOURCE MANAGEMENT FUNCTION IN FDI-INVESTED COMPANIES: EXPERIENCE FROM CENTRAL AND EASTERN EUROPE
}

\author{
Soňa Ferenčíková ${ }^{1}$, Daniel Krajčík ${ }^{2}$, Lucia Krajčíková ${ }^{3}$ \\ ${ }^{1}$ Vysoká škola manažmentu, Panónska cesta 17, 85104 Bratislava, SR \\ E-mail: sferencikova@vsm.sk \\ ${ }^{2}$ Ekonomická univerzita v Bratislave, Obchodná fakulta, Dolnozemská cesta 1, 85235 Bratislava, SR \\ E-mail:daniel.krajcik@euba.sk \\ ${ }^{3}$ Ekonomická univerzita v Bratislave, Obchodná fakulta, Dolnozemská cesta 1, 85235 Bratislava, SR \\ E-mail: lucia.krajcikova007@gmail.com
}

\begin{abstract}
The aim of the authors is to analyze the stages of the development of human resource management in Central and Eastern Europe since the change of the economic system and the beginning of transition to market economy as well as the consequences and the impact of the crisis on the human resource management function based on the survey conducted in 7 countries of Central and Eastern European region on the sample of 150 FDI-invested companies from manufacturing and service sector that were chosen randomly. 67 companies agreed to participate on the survey and complete the questionnaires. They were completed by the directors, heads or managers responsible for human resources. Human resource management has moved from simple administrative role to the position of strategic partner, however this new function is perceived, implemented and executed differently in the companies in the region. This position as well as HR priorities and activities have been severely touched by the economic and financial crisis in the region: the study shows the major trends in this area.
\end{abstract}

Keywords: Central and Eastern Europe, FDI-invested companies, human resource management, human resources as strategic partner.

JEL classification: M12, M54

Doručeno redakci: 13.11.2011; Recenzováno: 9.4.2013; 10.4.2013; Schváleno k publikování: 11.9.2013

\section{Introduction}

International experience proves that the factors determining whether the company achieves excellent or standard level of performance result from the organization's ability to work effectively with human resource. External environment volatility and rapid technological progress require innovative ways to enhance the organization performance and to ensure competitive advantage.

Managements of the companies have already understood that human capital is the primary source of competitive advantage and therefore it is necessary more than ever before, to pay particular attention to the human dimension of management.

The aim of the authors is to analyze the stages of the development of human resource management in Central and Eastern Europe since the change of the economic system and the beginning of transition to market economy in the first part of the article. They are doing that in the context of changes in this area and describe their experience with the development of human resource management function in the last two decades in the second part of the paper. They also study the consequences and the impact of the crisis on the human resource management function based on the survey conducted in 7 countries of Central and Eastern European region on the sample of 150 FDI-invested companies from manufacturing and 
service sector that were chosen randomly. 67 companies agreed to participate on the survey and the interviews that were conducted with the directors, heads and managers responsible for human resources.

\section{Development of human resource management}

We can specify different stages of the human resource management evolution based on the circumstances and human activity. Before we talk about human resource management, there were other related activities and steps developed (Amstrong 1999). Major ones are:

a) Personnel management - phase of development (1940s - 1950s): in this period, a full range of personnel services has been provided. Besides recruitment and staff record keeping, they were the special training and the training of the craftsmen provided. Personnel in charge of the employee care became the workforce management, which gradually engaged in the labor relations. However, workforce management activity remained at operational level.

b) Personnel management - phase of maturity (1960s - 1970s): in this period, the aforesaid services were extended to organization creation, development of managers and management, as well as systematic training and workforce planning. Increasing number of personnel directors became the members of top management. The rising amount of legislation caused that the personnel managers gradually became the labor law specialists.

c) Human resource management - first phase (1980s): The term human resource management has its origins in the works of American authors and later has been used by the business sphere as well. Personnel managers had to cope with the problems of corporate culture and market economy. The main issue was how the human resource management can influence the company results. Strategic approach to human resource management, remuneration according to work performance and development of performance management were gaining momentum in this phase. Power of unions was weakening.

d) Human resource management-second phase (1990s): this phase began as a reaction on the negative features of corporate culture such as greediness and individualism. Teamwork, strengthening of the powers and continuous improvement in learning organizations were much appreciated. The competencies have been discussed more and more, and the approach to processes, such as culture management, performance and remuneration management, performance-based appraisal and the development of managers, has been created. The recession has increased the emphasis on leaner and more flexible organizations with fewer levels of management and the concept of lifetime employment has ceased to be the norm. Personnel directors were often confronted with excessive redundancy or staff reduction. Personnel managers started to use benchmarking to identify and implement the best practices in human resource management.

Other authors describe following functions of human resource management (Evans, Pucik, Barsoux 2002, p. 52): building HRM, realigning HRM and steering with HRM. Under building HRM they understand getting the basics in place (HRM as the builder). Realigning HRM means adjusting to environmental change: strategic implementation and reconfiguration 
of HRM and HRM is understood as the change partner. Steering with HRM is focused on organizational capability development and HRM is considered to be the navigator.

\section{Strategic human resource management}

Within the context of transition from the personnel management to the human resource management, strategic approach becomes notable. This shift means a reorientation to integrated, proactive and strategic approach to company employees. In this context, strategy of human resource management is focused on that how human resource can be used to achieve the company's goals. (Ozbilgin, 2005)

However, it took more than a decade until the theory and later the practice have moved in the direction of understanding the strategic role of human resource management:

According to Armstrong, strategic human resource management is an integrated process aiming to achieve the strategic accord. Strategic approach to the management of human resource, is vertically linked with corporate strategy (Amstrong 2002, p. 119). The major proponents of the strategic role of human resource management could be found at the Ross School of Business at the University of Michigan where D. Ulrich and his team created the terms ,strategic partner" for human resource management and wrote many articles and books about the changing nature of human resource. (for example Ulrich, Brockbank 2005) In the meantime strategic role of human resource advocated by D. Ulrich and W. Brockbank, and many others has been moved to the role of human resources as a connector between outside and inside environment of the companies. (Ulrich 2011) All these processes and changes are of course caused and fueled by globalization (Pappova 2012).

\section{Globalization trends and new demands on human resources}

The phenomenon of globalization has created whole new value chains because of multinational corporations' rising role in world economy. Even the previously safe markets are dramatically changing. Companies are aggressively competing against domestic and foreign competitors for market shares. It is therefore not surprising that the number of companies employing expatriates, and the number of expatriates themselves is rising. Growing number of companies are born global" and they employ more and more local people as well. Globalization processes influence the development of organizations' human resource management. These processes bring new aspects into the development of company's internal environment, and they also affect the competitive environment in an entirely new way.

There are also significant changes in the labor market development as well. Understanding of career development has changed significantly. Personal responsibility of the employees for developing their own individual skills is emphasized. Professional knowledge and skills, not the current position in corporate hierarchy, are important for the employee's ability to succeed on the labor market. (Kelemen 2008). Employers gradually cross the borders to find the experience they need. Multicultural labor force is penetrating to the top management. Globalization forces managers to cope with the questions about that how to achieve and sustain competitive advantage, about that how to face the competition at home and abroad. Recruitment and training of the human resource needed to implement international or global strategy are therefore of crucial importance. (Workie 2009). The objective of strategic human resource management is to lead the way in this environment to interconnected practices and programs. (Armstrong 1999) Human resources and corporate strategy should be integrated. A key aspect is to ensure coherence of human management with the strategic focus of the organization (Ferencikova 2013). 


\section{Situation in HR development in Central and Eastern Europe}

More than two decades ago, the former socialist countries in Central and Eastern Europe (CEE) experienced a wave of revolutions as socialism (or communism) in Europe disappeared. The new social and economic order meant turmoil. Among the most significant changes was that these countries opened to foreign investments. One of the first challenges the foreign investors faced on the CEE markets was the need to hire skilled and talented local employees. In the early stages of the transition, their requirement was usually just foreign language fluency - French companies preferred French-speaking local nationals, German companies hired German-speaking employees, and other investors (including those from the USA or Great Britain) looked desperately for English speakers. This was especially true for HR positions - investors needed local liaison officers who could communicate with the local labor force in their native tongues and with foreign expatriates and their headquarters in the investors' language(s).

As such, the first HR positions were taken by those who studied foreign languages or foreign trade (the only economic discipline in which students were prepared to communicate with foreign customers) or by talented graduates with engineering, chemical, or technical degrees (depending on the activity of the foreign investor) who had studied some foreign language mostly as hobby or almost as an accident. Almost all of them were in their late 20s or early $30 \mathrm{~s}$ - the older generation did not have the requisite language skills.

This inaugural cohort of CEE HR managers was typically trained by their companies and in many cases mastered their jobs quickly. The first needs of the HR function in CEE were rather administrative. Because there was often not much a career path within the HR department, many HR managers moved to other top management positions in their companies, some of whom even rising to managing director or country manager positions. Those who stayed in the HR field felt driven to improve their skills because they did not get the classical HR education (even though they were over-educated in other areas). This need was later met by the foreign universities opening HR programs in CEE, followed in a couple years by new HR programs offered by local universities. Many HR executives "of Western origin" from headquarters looked to understand the region through the networks. Being "outsiders" from the West, they had often trouble grasping the idiosyncrasies of the CEE region.

"The composition of our membership has evolved over the years, with the changing HR landscape. Our typical member was initially a Western national based in a Western European city responsible for HR operations in CEE. Then it was a CEE national who re-located to the headquarters. These days, many members are CEE nationals based at CEE headquarters located in CEE capitals - some working for an emerging group of CEE multinationals. In other words, our membership base reflects several trends. First, the Western nationals were increasingly replaced in their CEE responsibilities by CEE nationals (the pool of talent in CEE gradually developed and was sufficiently rich to cover these positions). Second, the multinational companies in their search for cost cuts realized that the location of the headquarters in CEE makes sense. Third, some Central European companies formerly run in only one country began operating internationally, primarily in neighboring countries of CEE...." (Ferencikova, Gilett 2010, p. 38-39)

After the wave of the relocation of headquarters another wave began: CEE has emerged as a popular location for call, shared-service and support centers. These operations sometimes employ thousands of workers. The HR function has changed as well: at the end of the 90's, 
the HR function focused on building the basics. In the tumultuous mid to late 90's, it was oriented towards managing change. It has finally started to focus on strategy. Currently, many HR managers in the region confirm that their strategic role has been developing quickly; however, it is still far from the stage where they would like it. Therefore we have decided to check the progress in HR in a survey.

\section{Results of the survey of HR managers in Central and Eastern Europe Sample and method}

The survey results bring the companies' views reflecting current state and priorities in human resource management in the region of Central and Eastern Europe. We have also examined the involvement of HR into strategic phases and the evaluation of HR performance. The survey was conducted in the form of questionnaire (in English) that was distributed to the HR directors and managers in Central and Eastern European companies. We have addressed 150 randomly chosen FDI-invested companies from 11 countries of the region. The data processing is based on the 67 completed questionnaires (the response rate was 56\%) that we received from the 7 countries of the examined region: Slovakia, the Czech Republic, Hungary, Ukraine, Bulgaria, Romania and Slovenia. The survey was conducted in 2011 (Krajčíková 2011). Manufacturing (e.g. engineering, food industry) and services (e.g. financial services, consulting) are represented in the survey.

More than $70 \%$ of the replies were received from companies from Slovakia, but only $22,4 \%$ of the firms are of Slovak origin. The remaining $78 \%$ of companies are headquartered in other countries. Average number of the surveyed companies' employees is 855 i.e. majority companies represented in the survey are large entities.

\section{Priorities of the human resource management in crisis years}

Although the present-day market is unpredictable and costs have to be closely monitored, employees are still the key performance factor of each company. Rank of the priorities and their comparison in 2010 and 2011 are shown in the table below. The survey shows that the most important priorities in 2010 were an increase in employee engagement, performance management, training and development, employees' motivation increase. It is interesting that the top four HR priorities in 2011 are exactly the same as in the previous year. Nearly $35 \%$ of the companies stated cost reduction as the top priority in 2010 (This year was the year of strong economic crisis and recession, and it was followed by improved situation in 2011 when the region of Central and Eastern Europe showed much better macroeconomic results). In 2011, increase in employee engagement was stated as the top priority by $40 \%$ of the companies, which may have been connected with the expectations about the end of the crisis. 
Table 1: Priorities in human resource management in 2010 and 2011

\begin{tabular}{|lrrl|}
\hline \multicolumn{1}{|c|}{ Priority 2010 } & \multicolumn{1}{c|}{ Priority 2011 } \\
\hline Increase employee engagement & 1 & 1 & Performance management \\
Performance management & 2 & 2 & Increase employee engagement \\
T\&D of all employees & 3 & 3 & Increase employee motivation \\
Increase employee motivation & 4 & 4 & T\&D of all employees \\
\hline Cutting costs & 5 & 5 & Developing high potentials \\
Developing high potentials & 6 & 6 & Retaining talents \\
Compensation and benefits & 7 & 7 & Compensation and benefits \\
Recruitment & 8 & 8 & Attracting talents \\
Retaining talents & 9 & 9 & Recruitment \\
Attracting talents & 10 & 10 & Cutting costs \\
Employer branding & 11 & 11 & Career management \& succession planning \\
Career management \& succession planning & 12 & 12 & Employer branding \\
Internal HR marketing & 13 & 13 & Internal HR marketing \\
Outsourcing HR & 14 & 14 & Outsourcing HR \\
\hline
\end{tabular}

Source: authors' research

Results show that HR outsourcing and internal HR marketing were the least important in 2010 as well as in 2011. When comparing the years 2010 and 2011, we can see the biggest difference in the ranking of cost cutting. In 2010, it ranked in the top five. In 2011, respondents ranked it $10^{\text {th }}$.

\section{HR and the strategy development}

Nowadays, there is still a lot of discussion about the need to get closer to business and to create partnership between human resources and business itself. The survey showed that $69 \%$ of respondents agree that CEO of their company believes that HR management plays a key role in achieving business results. $66 \%$ of respondents stated that HR issues are taken into consideration while planning the business strategy of the company. More than half of the respondents stated that HR managers are able to discuss business topics. This clearly shows that HR is focused on human capital building in order to be consistent with the company's business objectives. It is noteworthy that $84 \%$ of the companies agreed that one of the most important differences between successful and unsuccessful company is the top management's support of HR strategy, policies and tools.

Table 2: Human resources department position

\begin{tabular}{|l|c|c|c|}
\hline & $\begin{array}{c}\text { strongly agree, } \\
\text { agree }\end{array}$ & $\begin{array}{c}\text { neither agree, nor } \\
\text { disagree }\end{array}$ & $\begin{array}{c}\text { disagree, strongly } \\
\text { disagree }\end{array}$ \\
\hline $\begin{array}{l}\text { Our CEO believes HR has a key role to play in achieving } \\
\text { good business results. }\end{array}$ & $69 \%$ & $23 \%$ & $8 \%$ \\
\hline $\begin{array}{l}\text { HR issues are fully taken into account in the business } \\
\text { planning process. }\end{array}$ & $66 \%$ & $20 \%$ & $14 \%$ \\
\hline HR managers are comfortable discussing business issues. & $57 \%$ & $36 \%$ & $7 \%$ \\
\hline $\begin{array}{l}\text { One of the most significant difference between successful } \\
\text { and less successful organization is commitment of the } \\
\text { Board of directors and CEO in HR strategy, policies and } \\
\text { tools. }\end{array}$ & $84 \%$ & $14 \%$ & $2 \%$ \\
\hline
\end{tabular}

Source: authors' research

The graph below shows the degree of HR involvement in the strategy development phases. The survey showed that HR is significantly involved in all phases associated with the strategy, e.g. planning phase, development, agreement phase and, of course, implementation phase. The greatest influence of HR can be seen in the implementation phase of the strategy. This fact proves how important is the role of HR management in the companies, however this role 
is not a creative or proactive one (as it is seen from the graph, the involvement of HR in the planning and development phase is relatively lower compared to implementation).

Figure 1: The level of participation human resources section on strategic phases

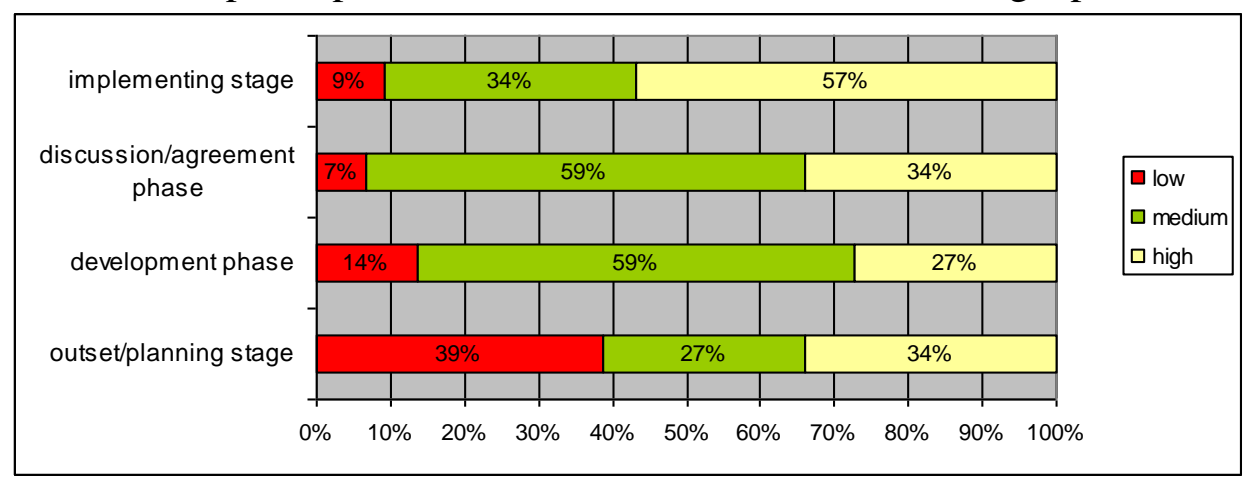

Source: authors' research

We have also surveyed what the opinions of the respondents about future development of HR are. Nearly two thirds of the respondents think that HR management will play more important role and will cooperate more closely with business. $30 \%$ of companies believe that the position of HR will not change in the future and only $6 \%$ of companies think that the function of HR will become less important and rather administrative.

HR therefore has to be more oriented into the future in the strategic and business way. $82 \%$ of respondents agreed that on the behalf of fulfilling future expectations of the organization, HR will have to develop new skills.

We have asked the surveyed companies about the importance and the time given to particular HR activities. Despite the above-mentioned strategic direction of HR, the responses (Graph 2) indicate that it is still more operational than strategic function. In the opinion of the respondents, HR administration is the most time-consuming, but also the least important task. Respondents stated consultations for managers as the most important and also timedemanding task of HR.

Figure 2: Activities of human resource department (importance versus time spent)

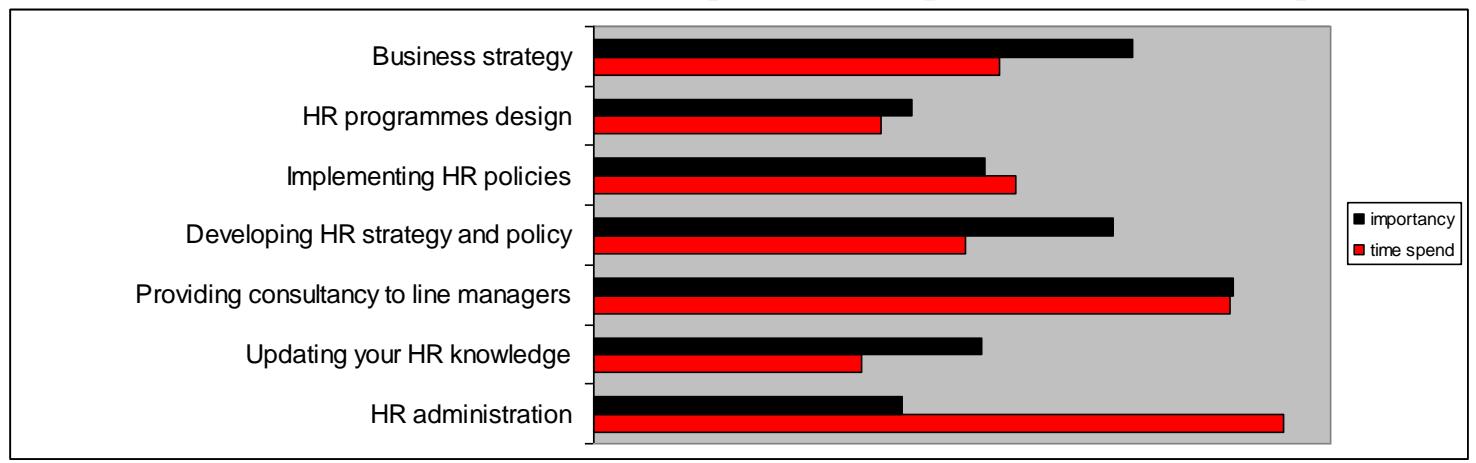

Source: authors' research

\section{Conclusion}

HR management has gone through several development phases. The development of HR started from the basic tasks and continued with recruitment, employee development and strategic management to the current position, when HR management has to react on rapidly changing economic environment. Nearly $70 \%$ of companies consider human resource 
management as a key prerequisite to achieve business results. HR issues are taken into account as early as in the planning phase of the company strategy. Performance management, employee commitment and engagement, motivation are the priorities of HR management in 2011 - and also the reason why the current position of HR is a great challenge.

If we study the results of the survey, it is visible that the crisis has kept or moved the HR function in CEE more into ,implementation role“, and the role of being strategic partner is still on the agenda. If we take into consideration that the survey showed that $70 \%$ of respondents agree that HR management plays a key role in achieving business results and the companies keep the HR function in the implementation phase more than in the strategic phase, we clearly see the discrepancy between the real and ,wished" position of HR.

The lack of progress is partially due to the economic development of the region: in the 90 's, the region was in a deep transitional economic recession. In spite of this recession, many foreign companies entering the region grew quickly due to the first-mover advantages, lack of local competition, and large, unsatisfied demand. Building the HR basics was a must at that time. Later, many of them needed to re-orient and change (partially also due to the development on the Western market) and HR had become a partner of the top management in the change process. The beginning of this millennium meant unprecedented growth in many activities in the $\mathrm{CEE}$ - the region has economically recovered and started to grow much faster than the developed countries of Europe (sometimes called "old Europe"). The HR function became more self-confident and started to move in a strategic direction. The economic crisis in 2008 has halted this process. HR in many companies has reverted to a more transactional role, focusing now on lay-offs, cost cuts, and the need to manage trade union relations. However, the need to be strategic is now much more important than even before. But as our results show, the HR function has to be blamed too because their employees and representatives first need to understand business and then they can be accepted as the strategic partners by the boards and executive management.

The crisis definitely moved HR into more pragmatic roles: to keep the employees engaged, motivated and loyal seem to be more important for the companies than to engage the HR function into strategies of the companies and to create a real strategic partner out of that.

And where do we see the future of HR now? The European space is becoming more homogenous, with the differences between East and West eroding. Strategic thinking in all areas of business activity, including HR, is essential to survival and growth. The same strategic thinking is needed throughout Europe, from Prague to Paris, Bratislava to Bonn.

\section{Acknowledgement}

This paper is part of a research project of the Ministry of Education, Science, Research and Sport of the Slovak Republic - VEGA 1/0461/12: "Management competences in foreign and local companies in Slovakia as a source of their competitive advantage in the era of the globalizing economy". 


\section{References}

[1] ARMSTRONG, M., 1999. Personální management. Praha : Grada. ISBN 80-7169614-5.

[2] ARMSTRONG, M., 2002. Řizení lidských zdrojů. Praha : Grada. ISBN 80-247-0469.

[3] EVANS, P., V. PUCIK, and J. L. BARSOUX, 2002. The Global Challenge. Frameworks for International Human Resource Management. New York: Irwin, ISBN 0-07-239730-6.

[4] FERENČÍKOVÁ, S. a kol., 2013. Medzinárodná expanzia firiem - stratégie, partnerstvá a l'udské zdroje. Bratislava: Iura Edition. ISBN 978-80-8078-532.

[5] FERENČÍKOVÁ, S. and A. GILLETT, 2010. Towards Single Europe. Two decades after liberalization, a region's workforce finds its leadership. HRO Europe, Summer 2010, p. 38-39.

[6] KELEMEN, J., 2008. Kapitoly o znalostnej spoločnosti. Bratislava: Iura Edition. ISBN 9788080782092

[7] KRAJČÍKOVÁ, L., 2011. Medzinárodné riadenie l'udských zdrojov - vybrané aspekty riadenia l'udských zdrojov v strednej a východnej Európe. Doktorandská dizertačná práca. Ved. S. Ferenčíková. Obchodná fakulta, Ekonomická univerzita Bratislava

[8] OZBILGIN, M., 2005. International Human Resources management: Theory and Practise. Palgrave Macmillan, ISBN 978-0-333-99323-1.

[9] PAPPOVÁ, A., 2012 Stratégie multinacionálnych korporácií a ich implikácie $v$ strednej a východnej Európe - vybrané aspekty. Doktorandská dizertačná práca. Ved. S. Ferenčíková. Obchodná fakulta, Ekonomická univerzita Bratislava

[10] ULRICH, D. and W. BROCKBANK, 2005. The HR Value Proposition. Boston: Harvard Business School Press. ISBN- 13: 978-1-59139-707-6.

[11] ULRICH, D., 2011. On changing nature of human resources. HR Summit, Budapest, October 26, mimeo.

[12] WORKIE, MENBERE T., 2009. Vývoj a perspektívy svetovej ekonomiky: globálna finančná a hospodárska kríza: pričiny - náklady - východiská. Bratislava: Ekonomický ústav Slovenskej akadémie vied. ISBN 9788071441755 